\title{
Structure of the herb stratum under different light regimes in the Submontane Atlantic Rain Forest
}

\author{
Lima, RAF* and Gandolfi, S.* \\ Laboratório de Ecologia e Restauração Florestal - LERF, Departamento de Ciências Biológicas, \\ Escola Superior de Agricultura 'Luiz de Queiroz', Universidade de São Paulo - USP, \\ Av. Pádua Dias, 11, CP 9, CEP 13418-900, Piracicaba, SP, Brazil \\ *e-mail: raflima@esalq.usp.br, sgandolf@esalq.usp.br
}

Received July 31, 2007 - Accepted September 4, 2007 - Distributed May 31, 2009

(With 2 figures)

\begin{abstract}
This study aimed to characterize the structure of the herb stratum in relation to light availability in the Submontane Atlantic Rain Forest at the Carlos Botelho State Park, SP, Brazil. Forty-one 10 x10 m plots were established under the closed canopy (18 plots), small and medium canopy gaps (11) and large canopy gaps dominated by Guadua tagoara (Ness) Kunth (12). Inside each plot, the line intercept method was applied to assess soil coverage as an estimate of density of herb stratum vegetation. Hemispherical photographs were taken at the centre of the plots to evaluate the annual light regime. Overall, Calathea communis Wanderley and S. Vieira had the greater mean coverage, followed by woody seedlings, ground ferns and other herbs (mainly, Araceae, Acanthaceae, Amaranthaceae and Cyperaceae). There were strong correlations among several groups of the herb stratum, such as the negative correlations between woody seedlings with the coverage of $C$. communis and with rocks. The analysis of the hemispherical photographs confirmed the difference among environments that led to significant differences in the soil coverage of the herb stratum vegetation but woody seedlings. For instance, $C$. communis showed great coverage in large gaps while ferns were more abundant in small and medium gaps and in the understorey. Other herbs, in turn, demonstrated bigger soil coverage in small and medium gaps. Although this study represents a rough assessment of the structure and composition of the herb stratum, the results found here illustrated the evident relation between herb species density and the environmental variation promoted by changes on canopy structure and topography.
\end{abstract}

Keywords: Calathea communis, canopy gaps, ground herbs, light.

\section{Estrutura do estrato herbáceo sob diferentes regimes de luz na Floresta Pluvial Atlântica Submontana}

\begin{abstract}
Resumo
O objetivo deste estudo foi caracterizar a estrutura do estrato herbáceo em relação à disponibilidade de luz na Floresta Pluvial Atlântica Submontana do Parque Estadual Carlos Botelho, SP, Brasil. Para tanto, foram instaladas 41 parcelas de $10 \times 10 \mathrm{~m}$ em ambientes sob o dossel fechado (18 parcelas), em clareiras pequenas e médias (11), e em clareiras grandes com dominância de Guadua tagoara (Ness) Kunth (12). Em cada parcela a percentagem de cobertura de solo, avaliada através do método de interceptação em linha, foi usada como estimativa da densidade da vegetação do estrato herbáceo. Fotografias hemisféricas foram tomadas ao centro de cada uma das parcelas para avaliar o regime anual de luz nos ambientes. No geral, a maior média obtida foi para Calathea communis Wanderley e S. Vieira, seguida por plântulas de regenerantes lenhosos, pteridófitas terrestres e outras ervas (principalmente Araceae, Acanthaceae, Amaranthaceae e Cyperaceae). Houve ainda fortes correlações entre vários grupos do estrato herbáceo, como as correlações negativas entre plântulas de regenerantes com a cobertura de $C$. communis e de rochas. A análise das fotografias hemisféricas confirmou a existência de ambientes com diferentes regimes de luz, que promoveram diferenças significativas na cobertura do solo de todos os grupos do estrato herbáceo, exceto para plântulas de regenerantes. Por exemplo, C. communis apresentou grande cobertura nas grandes clareiras, enquanto que as pteridófitas terrestres foram mais abundantes no sub-bosque e nas clareiras pequenas e médias. O grupo Outras Ervas, por sua vez, apresentou maiores coberturas nas clareiras pequenas e médias. Apesar de representar uma análise grosseira da estrutura e composição, os resultados encontrados aqui ilustraram uma evidente relação entre a densidade de formas de vida herbácea e as variações ambientais promovidas por mudanças na estrutura do dossel da floresta e na topografia.
\end{abstract}

Palavras-chave: Calathea communis, clareiras, ervas terrestres, luz. 


\section{Introduction}

The vegetation of the herb stratum, known for its high species richness, only started to be the main focus of tropical rain forest studies after the beginning of the eighties. Thereafter, succeeding studies proved that the inclusion of such stratum during floristic surveys may double the species list of a certain area (Gentry and Dodson, 1987; Poulsen, 1996; Laska, 1997). Composed by herbs, small shrubs and the initial life stages of other life forms (trees, lianas and hemiepiphytes: Gilliam et al., 1995; Zickel, 1995; Costa, 2004), the structure as well as the composition of the herb stratum can greatly influence woody regeneration (Ehrenfeld, 1980; Chandrashekara and Ramakrishnan, 1994; Davis et al., 1998; George and Bazzaz, 1999). Moreover, the presence of herbs near the forest ground aids the conservation of nutrients either by tissue stocks or by attenuating direct rainfall impacts (Moore and Vankat, 1986).

Despite of its greater ability of vegetative growth than tree species (Poulsen, 1996), ground herbs are expected to be more dispersal limited (Costa et al., 2005) and sensitive to environment changes, especially those linked to water and light supplies (Moore and Vankat, 1986; Dirzo et al., 1992). This is mainly a consequence of the low availability of light near the forest ground and of the simple and superficial root systems of herbs. These two reasons increase the light dependence of some herbs (Barik et al., 1992; Small and McCarthy, 2002) and their vulnerability to desiccation (Poulsen, 1996). Thus, although the magnitude and direction of the response to light and water supply differ among species, the richness, density and fertility of herbs may vary between forest environments (Chandrashekara and Ramakrishnan, 1994; Horvitz and Schemske, 1994; Sundarapandian and Swamy, 1996; Davis et al., 1998), creating patches with particular herb stratum composition and structure (Moore and Vankat, 1986).

On small spatial scales, two important regulators of the distribution of light and soil humidity in forested ecosystems are noticeably canopy structure and topography. Directly or indirectly, the association of these two aspects can promote great resource heterogeneity and therefore influence herb species development. However, very few studies have focused on the influence of at least one or both aspects on herb distribution and density (e.g. Poulsen \& Balslev, 1991; Poulsen, 1996; Small and McCarthy, 2002). In Brazilian tropical rain forests, the actual knowledge of the herb stratum is still scarce, and is mainly on the understanding of its composition and density related to canopy structure, topography and associated environment conditions. In this context, this study aimed to characterize the struct ure of the herb stratum under different light regimes and topographic positions in a Lower Montane Atlantic Rain Forest and to compare the soil coverage of different herb species between different forest environments.

\section{Material and Methods}

\subsection{Study site}

The present study was carried out in the Submontane Rain Forest of the Carlos Botelho State Park (PECB: Sete Barras, SP, Brazil) that has an approximate area of 37,644 ha. More specifically, the data collection was carried out inside a 10.24 ha permanent plot $(320 \times 320 \mathrm{~m}$; $24^{\circ} 10^{\prime} \mathrm{S}$ and $47^{\circ} 56^{\prime} \mathrm{W}$; $350 \mathrm{~m}$ above sea level) placed during the year of 2002 as part of a bigger thematic project that studies the diversity and dynamics of different forest formations in São Paulo state ("Diversidade, dinâmica e conservação em Florestas do Estado de São Paulo: 40 ha de parcelas permanentes" - BIOTA/FAPESP). Developed over granites and colluvionar deposits, the relief of the permanent plot is formed by hills and mountains characterized by very steep slopes and altitude that varies from 350-450 m above sea level. The soils are basically Haplic Cambisols, Fluvic Neosols (i.e., Fluvisols) and Haplic Gleysols generally clayey, medially profound to profound and that favor water retention (Rodrigues, 2005). An historical series of 62 years for the Sete Barras county indicates an annual average precipitation of $1,584 \mathrm{~mm}$ and average temperature around $22^{\circ} \mathrm{C}$ (DAEE/SP, 2006). However, the precipitation as well as the temperature, is not the same over the months of the years (Figure 1): the Thornthwaite water balance can show considerable deficits mainly between April and September when the monthly rainfall can get lower than $50 \mathrm{~mm}$. The climate is classified as humid subtropical with no dry season (Cfa) following the Köppen climate classification. The vegetation is Submontane Rain Forest (sensu Veloso, 1992) with an average canopy height of $20 \mathrm{~m}$ and an understorey where Euterpe edulis Mart. (palm-heart), small palms (Geonoma spp.) and tree ferns are abundant. These and other information on the physical environment, vegetation and flora of the permanent plot can be found in the scientific report of the thematic project cited above (Rodrigues, 2005).

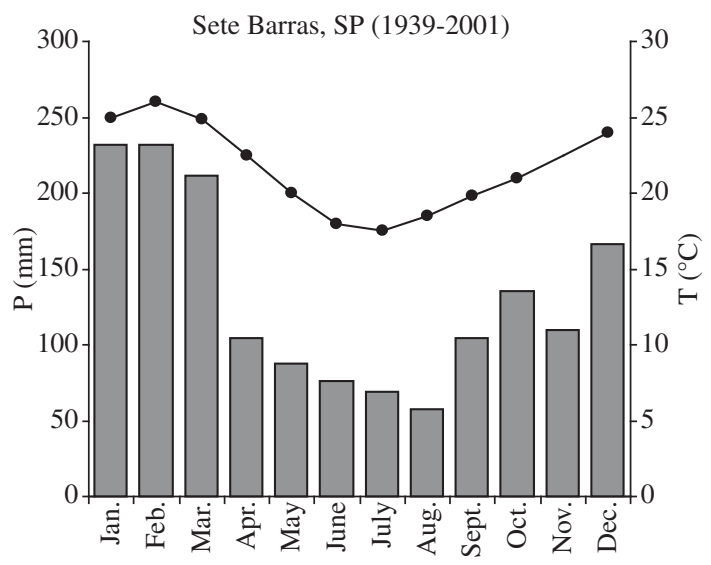

Figure 1. Monthly mean precipitation and temperature for Sete Barras, SP (data period 1939-2001). $\mathrm{P}=$ mean precipitation (bars); $\mathrm{T}=$ mean temperature (line). 


\subsection{Experimental design}

In January 2006, all canopy gaps sensu Runkle (1992) inside the plot limits were delimited and measured using the methods described in Lima (2007). Thereafter, $4110 \times 10 \mathrm{~m}$ plots were established under three light regimes that were representative amid the gradient of light availability namely: understorey; small and medium canopy gaps with sizes varying between 150 and $600 \mathrm{~m}^{2}$ sensu Runkle (1981), hereafter referred simply as gaps; and canopy gaps larger than $750 \mathrm{~m}^{2}$ sensu Runkle (1981). This last light environment is mainly represented by two large gaps, measuring approximately 1.7 and 1.1 ha, that contain few and isolated canopy trees involved by clumps of Guadua tagoara (Ness) Kunth, a woody and semiscandent bamboo species that usually reach heights of about 8 and $12 \mathrm{~m}$. Such environment will be mentioned henceforth simply as "bambuzal".

The randomized blocked design was adopted to place the $10 \times 10 \mathrm{~m}$ plots having the light regimes (understorey, gaps and "bambuzal") as the main factor and topography (valley bottom, slopes and ridges) as blocks. Although topographic positions were markedly different in environmental conditions, their division in the field was arbitrarily made: slopes were considered as the land fraction between two sudden changes in terrain steepness. As only recent gaps (approximate age smaller than five years old) with size bigger than $150 \mathrm{~m}^{2}$ (sensu Runkle, 1981) were considered during this study, the experimental design was based on the availability of gaps. Firstly, 11 gaps were randomly chosen among the different topographic positions. Next, 11 plots were established in the understorey adjacent to the chosen gaps always at a minimum distance of $10 \mathrm{~m}$ of any canopy gap and maintaining the same topographic position. To better describe the great heterogeneity in light conditions under continuous canopy (Lieberman et al., 1989), seven additional plots were placed under this light environment, totalizing 18 plots. In the "bambuzal", six plots were randomly placed in each of the two large canopy gaps, resulting in 12 sample units that were poorly balanced among the three topographic positions due to the arrangement of such big gaps inside the permanent plot.

\subsection{Light regime}

The light regime was assessed indirectly by the characterization of canopy structure using hemispherical photography. Images were taken at the centre of each plot with a digital camera (Nikon Coolpix 950, Nikon Corporation, Tokyo, JP) attached to a fish-eye lens (Fish-eye converter Nikkor FC-E8, Nikon Corporation, Tokyo, JP) and to a self-leveling camera mount (Delta T Devices Ltd., Cambridge, UK). All images were taken at $1.5 \mathrm{~m}$ above ground level on completely overcast days, to enhance image contrast and to avoid chromatic aberrations related to the equipment used (Frazer et al., 2001). Images were black and white and had 1:4 JPEG (Fine) compression and full size resolution $(1600 \times 1200)$, according to Frazer et al. (2001) and Inoue et al. (2004). Auto-focus and ex- position were set to infinite and no flash was used. Other camera settings selected were FishEye 1 mode, automatic shutter speed and $f / 2.6$ ( $f$-stop). At each plot, images were obtained using different values of exposure compensation (from -1.0 to $-0.3 \mathrm{eV}$ ) and the value that produced the image with higher contrast and sharpness was selected to carry image analysis (Hale and Edwards, 2002).

\subsection{Soil coverage}

In each of the 41 plots, an evaluation of the herb stratum was made, defined here as the vegetation lower than one metre tall. Therefore, it included ground herbs (i.e., non-woody obligate terrestrial species) and woody seedlings as well. Because many herbs present a rhizomatic growth habit, soil coverage was adopted as an estimate of herb density. Along with the evaluation of ground vegetation, the soil coverage of non-living components near the ground (as described below) was also evaluated using the same methods and hence are presented here together with the evaluation of ground herbs. To carry out this evaluation, the line intercept method was used, applied by means of seven $10 \mathrm{~m}$ parallel transects in each plot (70 $\mathrm{m}$ per plot). The length of the vertical projections below one metre tall of all groups evaluated was noted using a tape measure and a precision of $5 \mathrm{~cm}$. In the case of two or more groups with overlaid projections, the length was accounted for both groups. For ground herbs the interception of individual parts whose centre (stem) was both in or outside the plot limits was considered.

The division of the groups evaluated was made based on their frequencies in the study area as follows: Calathea [Calathea communis Wanderley and S. Vieira (Marantaceae)], Ferns, Woody seedlings (seedlings of erect herbs, shrubs and trees that usually reach heights taller than one metre), Others (other herb species, specially of the families Arecaceae, Acanthaceae, Amaranthaceae and Cyperaceae), Bamboo (living culms of G. tagoara), Bamboo litter (dead material of G. tagoara), bare Rocks, Roots and trunks (of large canopy trees), Debris (of fallen trees or branches) and Uncovered soil (stretches of exposed soil or soil covered only by dead leaves and/or tiny twigs).

\subsection{Data analysis}

Image analysis was carried out using the HemiView Canopy Analysis Software (version 2.1, AT Delta-T Devices Ltd., Cambridge, UK), set for local coordinates, altitude and magnetic declination. The Uniform Overcast Model was used and solar flux was set to $1,370.0$ W.m ${ }^{-2}$. Image classification (thresholding) was made by three different operators for each image to diminish possible operator effects. Each operator used the same size and magnetic alignment of images (saved in a specific file of the program) and classification was carried out using the same computer screen and light conditions. For each image six indexes of solar radiation and canopy structure were calculated: percentage of canopy openness (VisSky), total (TotBe), direct (DirBe) and diffuse 
radiation (DifBe) below the canopy, total leaf area index (LAI) and canopy uniformity (LAIDev). For each index, the mean value calculated for the three operators was used as the output for data analysis.

The soil coverage value for each plot was considered as the arithmetic average of the soil coverage of the seven transects (interception length/10 m). The data analysis was firstly made using descriptive stats and using the Spearman correlation coefficients. After, ground vegetation groups (i.e., ground herbs + woody seedlings) and light indexes had their distribution tested for normality and homogeneity of variances using the Shapiro-Wilk and Levene tests, respectively, previous to the Analysis of Variance (ANOVA) carried out with a significance level of 5\%. In case of statistical difference of means, the Tukey test was applied to distinguish group differences. All analysis and suggestions of data transformation were performed using the SAS System for Windows (version 8.2, SAS Institute Inc., Cary, EUA). Additionally, the performance of the experimental design adopted was evaluated for ground vegetation groups, that is, the analysis improvement related to the addition of blocks (in this study, topography). In this manner, the experimental error was calculated $\left[\mathrm{E}_{\mathrm{exp}}=100\left(\mathrm{SSE}_{\mathrm{res}}\right) /\left(\Sigma \mathrm{x}_{\mathrm{i}} / \mathrm{N}\right)\right.$, where $\mathrm{SSE}_{\mathrm{res}}=$ sum of square error and $\Sigma \mathrm{x}_{\mathrm{i}} / \mathrm{N}=$ average of the component] and the design relative efficiency $\left[R E=100\left(\left(f_{b}+1\right)\left(f_{i}+3\right)\right.\right.$ $\left.\operatorname{SSE}_{i} /\left(f_{i}+1\right)\left(f_{b}+3\right) S S E_{b}\right)$, where $f_{b}, f_{i}, S S S E_{b}$ and $S_{S E}$ are, correspondingly, the degrees of freedom and the sums of square error both for the randomized blocked $\left({ }_{b}\right)$ and completely randomized design $\left.\left({ }_{i}\right)\right]$.

\section{Results}

\subsection{Light regime}

The mean value $( \pm \mathrm{SD})$ of VisSky obtained for all plots combined was $11.29 \pm 6.79 \%$, varying considerably among environments from 5.91-39.53\% (Figure 2). Likewise, values of total solar radiation below the canopy (TotBe) varied from 498.1-4,712.9 mol.m $\mathrm{m}^{-2} \cdot \mathrm{y}^{-1}$ (mean \pm SD: 1,498.2 $\pm 939.4 \mathrm{~mol} \cdot \mathrm{m}^{-2} \cdot \mathrm{y}^{-1}$ ). LAI values ranged between 0.849 and 4.818 with an average of $2.876 \pm 0.930$. For all indexes calculated, there was strong evidence of differences between environments (Table 1). Canopy openness was larger in the "bambuzal" than in the gaps or understorey where the lower values of openness were always below $10 \%$ (Figure 2). Consequently, the radiation indexes (DirBe and DifBe) tended to be larger in the "bambuzal" than the other environments, although "bambuzal" and gaps did not present significant difference for DifBe. Leaf Area Index (LAI) was not different between gaps and the understorey but both were bigger than the "bambuzal". The index of canopy uniformity (LAIDev) had a peculiar feature, being larger in gaps pursued by the "bambuzal" and understorey, all presenting significant differences among each other.

\subsection{Soil coverage}

The sum of all ground herbs (i.e., groups Calathea, Ferns and Other herbs) showed largest soil cover average followed by uncovered soil and woody seedlings (Table 2). All other groups evaluated (i.e., Bamboo litter, Debris, Rocks, Roots and trunks) were less common, even when pulled altogether. When values are analyzed separately this group order suffers minor changes. All ground herbs presented the highest coverage value found for a single plot. Moreover, ground herbs occurred in all plots, as well as the uncovered soil and seedling groups. When analyzed separately, the group constituted by the species $C$. communis was not present in only one plot and individually obtained the second largest maximum value. The group Other herbs was comparably frequent, although not as abundant as Calathea.

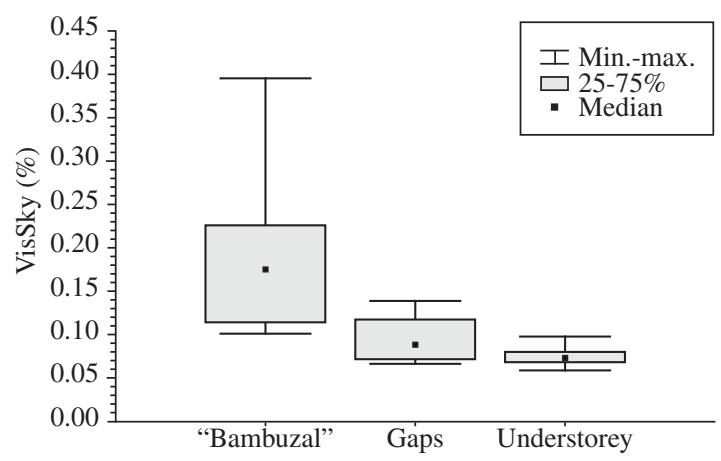

Figure 2. Proportion of canopy openness (VisSky) acquired from hemispherical photographs in the three studied light environments.

Table 1. Results of the Analysis of Variance (ANOVA) applied to the light and canopy structure indexes obtained from hemispherical photography. Different superscript letters indicate differences $(\mathrm{p}<0.05)$ pointed by the Tukey test. Radiation values (DirBe, DifBe, TotBe) in mol. $\mathrm{m}^{-2} \cdot \mathrm{y}^{-1}$ and values of canopy openness (VisSky) in percentage. See text for complete variable names.

\begin{tabular}{lcccc}
\hline \multicolumn{1}{c}{ Index } & "Bambuzal” $(\mathbf{N}=\mathbf{1 2})$ & Gaps $(\mathbf{N}=\mathbf{1 1})$ & Understorey $(\mathbf{N}=\mathbf{1 8})$ & Statistics \\
\hline DirBe & $300.79 \pm 145.39^{\mathrm{a}}$ & $164.74 \pm 46.77^{\mathrm{b}}$ & $118.14 \pm 16.19^{\mathrm{c}}$ & $\mathrm{F}=35.38^{*}$ \\
DifBe & $2,103.77 \pm 1,064.46^{\mathrm{a}}$ & $1,308.19 \pm 484.96^{\mathrm{a}}$ & $791.19 \pm 197.19^{\mathrm{b}}$ & $\mathrm{F}=16.26^{* *}$ \\
TotBe & $2,404.46 \pm 1,196.14^{\mathrm{a}}$ & $1,472.90 \pm 518.61^{\mathrm{b}}$ & $909.32 \pm 204.66^{\mathrm{c}}$ & $\mathrm{F}=17.91^{* *}$ \\
LAI & $1.886 \pm 0.423^{\mathrm{a}}$ & $3.715 \pm 0.795^{\mathrm{b}}$ & $3.024 \pm 0.612^{\mathrm{b}}$ & $\mathrm{F}=24.84$ \\
LAIDev & $2.750 \pm 0.380^{\mathrm{a}}$ & $3.693 \pm 0.962^{\mathrm{b}}$ & $2.283 \pm 0.364^{\mathrm{c}}$ & $\mathrm{F}=19.81^{* *}$ \\
VisSky & $18.70 \pm 8.51^{\mathrm{a}}$ & $9.39 \pm 2.64^{\mathrm{b}}$ & $7.51 \pm 1.10^{\mathrm{c}}$ & $\mathrm{F}=35.50^{*}$ \\
\hline
\end{tabular}

*Data inversely transformed; and **data log transformed 
Regarding the Spearman correlation coefficients, there were strong positive and negative correlations between several groups (Table 3). The uncovered soil group, for instance, demonstrated strong negative correlations with Calathea, Bamboo litter and Bamboo, and positive correlations with Ferns, Rocks and Roots and trunks. Calathea presented strong correlations with nearly the same groups

Table 2. Descriptive statistics of the herb stratum groups evaluated $(\mathrm{N}=41)$. All values in percentage.

\begin{tabular}{lcl}
\hline \multicolumn{1}{c}{ Group } & Mean \pm SD $(\%)$ & Range (\%) \\
\hline Ground herbs & $39.40 \pm 18.46$ & $5.00-81.85$ \\
Calathea & $22.70 \pm 19.23$ & $0.00-65.00$ \\
Ferns & $8.84 \pm 7.01$ & $0.71-28.71$ \\
Other herbs & $7.86 \pm 6.65$ & $0.00-25.29$ \\
Uncovered soil & $30.29 \pm 22.32$ & $0.86-67.07$ \\
Woody seedlings & $15.76 \pm 6.95$ & $4.86-30.57$ \\
Other groups & $14.07 \pm 12.09$ & $0.48-45.86$ \\
Bamboo litter & $7.94 \pm 13.21$ & $0.00-43.57$ \\
Wood debris & $3.32 \pm 4.45$ & $0.00-21.57$ \\
Rocks & $1.93 \pm 4.67$ & $0.00-16.43$ \\
Roots and trunks & $0.88 \pm 1.25$ & $0.00-6.36$ \\
Bamboo & $1.77 \pm 3.30$ & $0.00-13.14$ \\
\hline
\end{tabular}

as uncovered soil did, but in an opposite way. Besides the negative correlation with Calathea, woody seedlings showed significant negative correlation only with Rocks. Ferns were related negatively with Bamboo and Bamboo litter and positively with Other herbs and Rocks. Another relation that is worth mentioning was the positive correlation obtained between Other herbs and Debris.

The ANOVA indicated significant differences between environments for all ground herbs but not for woody seedlings (Table 4). The soil coverage percentages of uncovered soil were bigger in the understorey, in opposition to Calathea that had larger percentages in the "bambuzal". On the other hand, ferns were less abundant in the "bambuzal" when compared to its coverage in the understorey and gaps. Other herbs presented larger values in gaps than in the understorey and in the "bambuzal". It is noteworthy, however, that some of these variables did not obtain satisfactory experimental errors $(<50 \%$; Table 4$)$, strikingly those with low coverage values. For most groups, the addition of the topographic position (i.e., blocks) proved to enhance the experiment efficiency (ER $\geq 100 \%$ ), that was particularly true for Calathea and woody seedlings.

Table 3. Spearman correlation coefficients of the herb stratum groups evaluated. Superscript letters indicate the probability value associated to the coefficient: $\mathrm{a}=\mathrm{p}<0.1 ; \mathrm{b}=\mathrm{p}<0.05 ; \mathrm{c}=\mathrm{p}<0.01 ; \mathrm{d}=\mathrm{p}<0.001$.

\begin{tabular}{|c|c|c|c|c|c|c|c|c|c|c|}
\hline Group & $\begin{array}{c}\text { Uncovered } \\
\text { Soil } \\
\end{array}$ & Calathea & $\begin{array}{c}\text { Woody } \\
\text { seedlings }\end{array}$ & Ferns & $\begin{array}{c}\text { Bamboo } \\
\text { litter }\end{array}$ & $\begin{array}{l}\text { Other } \\
\text { herbs }\end{array}$ & $\begin{array}{l}\text { Wood } \\
\text { debris }\end{array}$ & Rocks & Bamboo & $\begin{array}{c}\text { Roots and } \\
\text { trunks }\end{array}$ \\
\hline $\begin{array}{l}\text { Uncovered } \\
\text { soil }\end{array}$ & 1 & - & - & - & - & - & - & - & - & - \\
\hline Calathea & $-0.731^{\mathrm{d}}$ & 1 & - & - & - & - & - & - & - & - \\
\hline $\begin{array}{l}\text { Woody } \\
\text { seedlings }\end{array}$ & 0.226 & $-0.504^{\mathrm{d}}$ & 1 & - & - & - & - & - & - & - \\
\hline Ferns & $0.340^{\mathrm{b}}$ & $-0.404^{\mathrm{c}}$ & -0.017 & 1 & - & - & - & - & - & - \\
\hline $\begin{array}{l}\text { Bamboo } \\
\text { litter }\end{array}$ & $-0.801^{\mathrm{d}}$ & $0.432^{\mathrm{c}}$ & 0.007 & $-0.538^{\mathrm{d}}$ & 1 & - & - & - & - & - \\
\hline Other herbs & -0.098 & -0.003 & 0.169 & $0.504^{\mathrm{d}}$ & -0.054 & 1 & - & - & - & - \\
\hline Wood debris & -0.248 & 0.150 & 0.088 & 0.066 & 0.024 & $0.392^{\mathrm{b}}$ & 1 & - & - & - \\
\hline Rocks & $0.318^{\mathrm{b}}$ & 0.030 & $-0.483^{\mathrm{c}}$ & $0.311^{\mathrm{b}}$ & $-0.595^{\mathrm{d}}$ & 0.238 & 0.033 & 1 & - & - \\
\hline Bamboo & $-0.840^{\mathrm{d}}$ & $0.564^{\mathrm{d}}$ & -0.064 & $-0.530^{\mathrm{d}}$ & $0.910^{\mathrm{d}}$ & -0.132 & 0.101 & $-0.590^{\mathrm{d}}$ & 1 & - \\
\hline $\begin{array}{l}\text { Roots and } \\
\text { trunks }\end{array}$ & $0.646^{\mathrm{d}}$ & $-0.533^{\mathrm{d}}$ & 0.107 & 0.185 & $-0.425^{\mathrm{c}}$ & -0.001 & $-0.274^{\mathrm{a}}$ & $0.309^{\mathrm{b}}$ & $-0.544^{\mathrm{d}}$ & 1 \\
\hline
\end{tabular}

Table 4. Results of the Analysis of Variance (ANOVA) applied to the herb stratum groups. Different superscript letters indicate differences $(\mathrm{p}<0.05)$ pointed by the Tukey test. All values in percentage. $\mathrm{ns}=$ not significant.

\begin{tabular}{lcccccc}
\hline \multicolumn{1}{c}{ Group } & \multicolumn{3}{c}{ Mean \pm SD } & Statistics & \multicolumn{2}{c}{ Sampling } \\
\cline { 2 - 4 } & $\begin{array}{c}\text { "Bambuzal" } \\
(\mathbf{N}=\mathbf{1 2})\end{array}$ & $\begin{array}{c}\text { Gaps } \\
(\mathbf{N}=\mathbf{1 1})\end{array}$ & $\begin{array}{c}\text { Understorey } \\
(\mathbf{N}=\mathbf{1 8})\end{array}$ & & $\begin{array}{c}\text { Experimental } \\
\text { error }\end{array}$ & $\begin{array}{c}\text { Relative } \\
\text { efficiency }\end{array}$ \\
\hline Ground herbs & $51.55 \pm 13.56^{\mathrm{a}}$ & $47.17 \pm 16.99^{\mathrm{a}}$ & $26.55 \pm 13.96^{\mathrm{b}}$ & $\mathrm{F}=8.25$ & 32.71 & 99.83 \\
Calathea & $41.82 \pm 12.89^{\mathrm{a}}$ & $23.14 \pm 20.63^{\mathrm{b}}$ & $9.68 \pm 8.62^{\mathrm{c}}$ & $\mathrm{F}=14.73$ & 47.87 & 122.92 \\
Ferns & $3.64 \pm 1.87^{\mathrm{a}}$ & $10.33 \pm 4.52^{\mathrm{b}}$ & $11.40 \pm 8.59^{\mathrm{b}}$ & $\mathrm{F}=3.35$ & 78.16 & 94.52 \\
Others & $6.09 \pm 7.28^{\mathrm{a}}$ & $13.70 \pm 6.24^{\mathrm{b}}$ & $5.47 \pm 4.09^{\mathrm{a}}$ & $\mathrm{F}=5.12$ & 79.90 & 103.47 \\
Woody seedlings & $14.42 \pm 6.15^{\mathrm{ns}}$ & $17.37 \pm 7.53^{\mathrm{ns}}$ & $15.68 \pm 7.28^{\mathrm{ns}}$ & $\mathrm{F}=0.30$ & 43.47 & 105.39 \\
\hline
\end{tabular}




\section{Discussion}

\subsection{Light regime}

Forest canopy is a major determinant of forest microclimate, particularly in respect to quantity, quality and availability of sunlight in time and space (Jennings et al., 1999). Despite the limitations in the use of hemispherical photography to describe canopy structure and light entrance (Rich, 1990), this technique proved to be capable of detecting differences in the annual light regime of the environments selected here. Therefore, environments could be differentiated not only in terms of subjective and dichotomous denominations (e.g. gaps and understorey) but also in terms of continuous measures of potential light incidence, which certainly has greater ecological meaning (Brown, 1990). Therefore, canopy openness and thus total below canopy radiation were larger in the "bambuzal", followed by gaps and understorey. Griscom and Ashton (2003) also found higher light incidences in bamboo-dominated stands than in bamboo-free stands. Although mean values may vary, the differences found here are consistent to those of Muniz (2004), in the same study area, and to those of other studies comparing light indexes between gaps and understorey environments (Rich et al., 1993; Brown, 1990).

In spite of the distinction of light indexes among environments, there was substantial variation within environments. In the "bambuzal", dense bamboo clumps often reduced direct light incidence and hence generated values more variable among plots. Besides its foliage, bamboo culms inclined near ground level are additional sources of light interception. A similar feature was observed for some gaps originating from dead-standing canopy trees that, in addition to lower understorey vegetation damage, held up liana tangles able to reduce light entrance. The use of gaps of different ages (i.e. internal vegetation height) may also have generated in light availability inside gaps (Dirzo et al., 1992). Moreover, the cutting of a large Guapira opposita (Vell.) Reitz individual (approximately $26 \mathrm{~cm}$ in diameter) by palm-heart harvesters, during the study period, put the light regime of an understorey plot closer to gap light environments. Finally, only one image at the plot centre may not be able to characterize well the great spatial variability of light incidence (Jennings et al., 1999) constraining the full description of plot light regime.

\subsection{Soil coverage}

In respect to soil coverage by herbs, the mean values and frequencies found here $(39.4 \%)$ were quite close to those found by Kozera and Rodrigues (2005) for other Submontane Rain Forest (30.6\% for herbs lower than $1.5 \mathrm{~m}$ tall). It is important to stress that an average of around $30 \%$ of the soil area sampled was uncovered, i.e. available for species colonization. Although different among environments (Lima, 2007), the percentage of uncovered soil was only indirectly related to canopy openness because of the increase of ground herb coverage under more open environments, especially Calathea. Thus, the relatively high values of uncovered soil encountered $(30.3 \%)$ cannot be interpreted as a suitable space for colonization without considering species requirements related to microclimate limitations and/or inter-specific competition for space.

Costa (2004) also identified a Marantaceae species (Monotogma spicatum Aubl. Macbr.) as the one with greater relative coverage and frequency in an Amazonian Terra-firme Forest. The genus Calathea obtained large values of coverage in the studies of Kozera and Rodrigues (2005); Lima and Moura (2006) as well, reaching in this last study an individual value of $74 \%$. Large values of Calathea had already been noticed by Klein (1979) in a Submontane Rain Forest and by Meira-Neto and Martins (2003) in a Semi-deciduous Forest. Poulsen and Balslev (1991), Dirzo et al. (1992) e Zickel (1995), however, did not find any Marantaceae species with importance comparable to our results. On the other hand, in the above-cited studies the values of fern coverage were larger than the one found here. Kozera and Rodrigues (2005) found Cyathea corcovadensis Domin as the species with the largest coverage while Costa (2004) found Trichomanes pinnatum Hedw. as the most abundant herb. Poulsen and Balslev (1991) also found fern species with cover values much higher than those observed here. Nonetheless, it is noteworthy that such differences may reflect the larger number of plots placed in enlightened environments here compared to other studies. This statement may be true not only for ferns, but for Calathea as well.

Still regarding ferns, soil coverage of this group was positively correlated with the presence of rocks, probably as an indirect effect of topography. Bare rocks were more common in valley bottoms where soil and air humidity is higher (Oliveira-Filho et al., 1998; Clinton, 2003), favoring some fern species development (Poulsen, 1996; Costa et al., 2005). Another correlation that deserves attention is the positive relation between Uncovered soil and Roots and trunks (related to the presence of large canopy individuals) suggesting canopy coverage as an important determinant of herb species coverage (cf. Turner et al., 1996). Such a fact is somehow confirmed by the negative correlation of Uncovered soil and Calathea. Another interesting result is related to the negative correlation of woody seedlings with the coverage of Calathea and Rocks. In a certain way these two last groups, more abundant in valley bottoms (Lima, 2007), seem to be linked to some process that constrains the establishment of the group woody seedlings. Rocks are clearly not a good substrate for many plant species development (but see Lima, 2007 for examples of species able to reach the adult phase in the PECB). Lima and Moura (2006) have already suggested some negative aspects of C. communis over the establishment of woody species, in a similar way to those cited by other authors (Ehrenfeld, 1980; Chandrashekara and Ramakrishnan, 1994; Davis et al., 1998; George and Bazzaz, 1999).

This study showed differences in the soil coverage by herb species between forest environments, as emphasized by many authors (Barik et al., 1992; Chandrashekara and Ramakrishnan, 1994; Horvitz and Schemske, 1994; 
Sundarapandian and Swamy, 1996; Small and McCarthy, 2002). Such differences appear to be related to an overall better development of herbs in more illuminated environments. C. communis, for instance, presented increasing values of coverage according to light incidence. Nevertheless, the results for other herb species suggest that exceedingly illuminated environments (i.e. "bambuzal") may be restrictive to some species, particularly ferns. On the other hand, the group Others was favored in canopy gaps where radiation, soil humidity (Moore and Vankat, 1986) and the availability of special regeneration substrates (e.g. fallen debris - see correlation between Other herbs and Wood debris, Table 3) may be more adequate.

For $C$. communis both light and topography had significant effects on its soil coverage that peaks at illuminated places in valley bottoms. Probably, the association of this species with valley bottoms may be linked to soil humidity (Klein, 1979), as suggested for other species of the genus (Poulsen and Balslev, 1991; Kennedy, 2000 apud Wanderley and Vieira, 2002; Costa et al., 2005). Therefore, C. communis seem to fit quite well to the pioneer group due to its occurrence preferentially on illuminated environments, soil seed bank persistence (Souza, SCPM. pers. comm.) and fast growth (Lima, RAF. pers. obs.). As for other species of the genus, seeds are small and probably dispersed by ants. For C. ovandensis Matuda, Horvitz and Schemske (1994) found that seeds are significantly dependent upon gaps for their germination, being able to remain viable in the soil for at least two years. For $C$. micans (L. Mathieu) Körn. there was higher reproductive success with light increases (Le Corff, 1993), although no difference was found significant considering germination under different light regimes (Le Corff, 1996).

Since many herb species are more susceptible to desiccation (Poulsen, 1996), topography (and the resulting environmental variations on soil humidity and nutrients: Costa et al., 2005) influence their density, distribution and soil coverage (Poulsen and Balslev, 1991; Barik et al., 1992; Turner et al., 1996; Davis et al., 1998; Small and McCarthy, 2002). Even though only C. communis was evaluated individually, there was an indication of such topographical effect on the groups Others herbs and Woody seedlings as well, when the inclusion of topography in the ANOVA removed a great part of the noise associated to the group distribution between environments (Relative efficiency $=103$ and $105 \%$, respectively). Ferns, however, did not present a similar suggestion in respect to topography (Relative efficiency $<100 \%$ ) probably because it represents a very diverse group with species having quite different requirements. On the other hand, the differences between light environments have shown the conspicuous relationship between herb species coverage and canopy structure. Differences in the composition and species coverage certainly existed within the groups Others and Ferns (cf. Dirzo et al., 1992), differences that were not detected in this study due to methodological restrictions. Therefore, more detailed future research in respect to the composition of the herb stratum (e.g., Poulsen, 1996; Costa et al., 2005) will adjoin more information on the distribu- tion and performance of herb species throughout the existing forest heterogeneity.

Acknowledgements - R.A.F. Lima is grateful for the scholarship provided by CNPq (Process no. 132938/2005-7). This study was supported by the project 'Diversidade, dinâmica e conservação em Florestas do Estado de São Paulo: 40 ha de parcelas permanentes' (Proc. no.: 9/09635-0) within the BIOTA/ FAPESP program (www.biota.org.br). The authors are grateful to the Instituto Florestal de São Paulo and to the administration of the PECB for making this work possible.

\section{References}

BARIK, SK., PANDEY, HN., TRIPATHI, RS. and RAO, P., 1992. Microenvironmental variability and species-diversity in treefall gaps in a Subtropical Broadleaved Forest. Vegetatio, vol. 103 , no. 1, p. 31-40.

BROWN, ND., 1990. Dipterocarp regeneration in tropical rain forest gaps of different sizes. Trinity: Oxford University. 169p. Tese de Doutorado.

CHANDRASHEKARA, UM. and RAMAKRISHNAN, PS., 1994. Successional patterns and gap phase dynamics of a humid tropical forest of the Western Ghats, India: ground vegetation, biomass, productivity and nutrient cycling. Forest Ecology and Management, vol. 70, no. 1-3, p. 23-40.

CLINTON, BD., 2003. Light, temperature, and soil moisture responses to elevation, evergreen understorey, and small canopy gaps in the southern Appalachians. Forest Ecology and Management, vol. 186, no. 1-3, p. 243-255.

COSTA, FRC., 2004. Structure and composition of the groundherb community in a terra-firme Central Amazonian forest. Acta Amazonica, vol. 34, no. 1, p. 53-59.

COSTA, FRC., MAGNUSSON, WE. and LUIZÃO, RCC., 2005. Mesoscale distribution patterns of Amazonian understorey herbs in relation to topography, soil and watersheds. Journal of Ecology, vol. 93, no. 1, p. 863-878.

DAEE/SP, 2006. Banco de dados pluviométricos do Estado de São Paulo. Available from: <http://www.daee.sp.gov.br/ hidrometeorologia/bancodados.htm >. Access in: 16 de Dezembro de 2006.

DAVIS, MA., WRAGE, KJ. and REICH, PB., 1998. Competition between tree seedlings and herbaceous vegetation: support for a theory of resource, supply and demand. Journal of Ecology, vol. 86 , no. 5 , p. $652-661$.

DIRZO, R., HORVITZ, CC., QUEVEDO, H. and LOPEZ, MA., 1992. The effects of gap size and age on the understorey herb community of a Tropical Mexican Rain Forest. Journal of Ecology, vol. 80, no. 4, p. 809-822.

EHRENFELD, JG., 1980. Understory response to canopy gaps of varying size in a mature oak forest. Bulletin of the Torrey Botanical Club, vol. 107, no. 1, p. 29-41.

FRAZER, GW., FOURNIER, RA., TROFYMOW, JA. and HALL, RJ., 2001. A comparison of digital and film fisheye photography for analysis of forest canopy structure and gap light transmission. Agricultural and Forest Meteorology, vol. 109, no. 4, p. 249-263.

GENTRY, AH. and DODSON, C., 1987. Contribution of nontrees to species richness of a tropical rain forest. Biotropica, vol. 19 , no. 2 , p. 149-156. 
GEORGE, LO. and BAZZAZ, FA., 1999. The fern understory as an ecological filter: emergence and establishment of canopytree seedlings. Ecology, vol. 80, no. 3, p. 833-845.

GILLIAM, FS., TURRILL, NL. and ADAMS, MB., 1995. Herbaceous-layer and overstory species in clear-cut and mature Central Appalachian Hardwood Forests. Ecological Applications, vol. 5, no. 4, p. 947-955.

GRISCOM, BW. and ASHTON, PM., 2003. Bamboo control of forest succession: Guadua sarcocarpa in Southeastern Peru. Forest Ecology and Management, vol. 175, no. 1-3, p. 445-454.

HALE, SE. and EDWARDS, C., 2002. Comparison of film and digital hemispherical photography across a wide range of canopy densities. Agricultural and Forest Meteorology, vol. 112, no. 1, p. 51-56.

HORVITZ, CC. and SCHEMSKE, DW., 1994. Effects of dispersers, gaps, and predators on dormancy and seedling emergence in a tropical herb. Ecology, vol. 75, no. 7, p. 1949-1958.

INOUE, A., YAMAMOTO, K., MIZOUE, N. and KAWAHARA, Y., 2004. Effects of image quality, size and camera type on forest light environment estimates using digital hemispherical photography. Agricultural and Forest Meteorology, vol. 126, no. 1-2, p. 89-97.

JENNINGS, SB., BROWN, ND. and SHEIL, D., 1999. Assessing forest canopies and understorey illumination: canopy closure, canopy cover and other measures. Forestry, vol. 72, no. 1, p. 59-73.

KLEIN, RM., 1979. Ecologia da flora e vegetação do Vale do Itajaí. Sellowia, vol. 31, no. 1, p. 9-164.

KOZERA, C. and RODRIGUES, RR., 2005. Floresta ombrófila densa submontana: florística e estrutura do estrato inferior. In MARQUES, MCM. and BRITEZ, RM. (Orgs.). História natural e conservação da Ilha do Mel. Curitiba: Editora UFPR, p. 103-123.

LASKA, MS., 1997. Structure of understory shrub assemblages in adjacent secondary and old growth tropical wet forests, Costa Rica. Biotropica, vol. 29, no. 1, p. 29-37.

Le CORFF, J., 1993. Effects of light and nutrient availability on chasmogamy and cleistogamy in an understory tropical herb, Calathea micans (Marantaceae). American Journal of Botany, vol. 80, no. 12, p. 1392-1399.

, 1996. Establishment of chasmogamous and cleistogamous seedlings of an ant-dispersed understory herb, Calathea micans (Marantaceae). American Journal of Botany, vol. 83, no. 2, p. $155-161$.

LIEBERMAN, M., LIEBERMAN, D. and PERALTA, R., 1989. Forests are not just swiss cheese: canopy stereogeometry of nongaps in tropical forests. Ecology, vol. 70, no. 3, p. 550-552.

LIMA, RAF., 2007. Regime de distúrbio e dinâmica da regeneração natural na Floresta Pluvial Atlântica Submontana. Piracicaba: ESALQ-USP. 233p. Dissertação de Mestrado.

LIMA, RAF. and MOURA, LC., 2006. Canopy gap colonization in the Atlantic Montane Rain Forest. Brazilian Archives of Biology and Technology, vol. 49, no. 6, p. 953-965.

MEIRA-NETO, JAA. and MARTINS, FR., 2003. Estrutura do sub-bosque herbáceo-arbustivo da mata da silvicultura, uma floresta estacional semidecidual no município de Viçosa-MG. Revista Árvore, vol. 27, no. 4, p. 459-471.

MOORE, MR. and VANKAT, JL., 1986. Responses of the herb layer to the gap dynamics of a Mature Beech-Maple Forest. American Midland Naturalist, vol. 115, no. 2, p. 336-347.
MUNIZ, MRA., 2004. Estudo de regime de luz nas quatro principais formações fitogeográficas no Estado de São Paulo durante o inverno do ano de 2003. Campinas: Universidade de Campinas. 169p. Dissertação de Mestrado.

OLIVEIRA-FILHO, AT., CURI, N., VILELA, EA. and CARVALHO, DA., 1998. Effects of canopy gaps, topography, and soils on the distribution of woody species in a central Brazilian Deciduous Dry Forest. Biotropica, vol. 30, no. 3, p. 362-375.

POULSEN, AD., 1996. Species richness and density of ground herbs within a plot of lowland rainforest in north-west Borneo. Journal of Tropical Ecology, vol. 12, no. 2, p. 177-190.

POULSEN, AD. and BALSLEV, H., 1991. Abundance and cover of ground herbs in an Amazonian Rain Forest. Journal of Vegetation Science, vol. 2, no. 3, p. 315-322.

RICH,PM., 1990. Characterizing plant canopies with hemispherical photographs. Remote Sensing Reviews, vol. 5, no. 1, p. 13-29.

RICH, PM., CLARK, DB., CLARK, DA. and OBERBAUER, SF., 1993. Long-term study of solar-radiation regimes in a Tropical Wet Forest using quantum sensors and hemispherical photography. Agricultural and Forest Meteorology, vol. 65, no. 1-2, p. 107-127.

RODRIGUES, RR. (Coord.)., 2005. Parcelas Permanentes em 40ha de florestas do Estado de São Paulo: uma experiência interdisciplinar. $4^{\circ}$ Relatório temático do projeto "Diversidade, dinâmica e conservação em florestas do estado de São Paulo: 40 ha de parcelas permanentes" apresentado à FAPESP (Processo no: 1999/09635-0). Piracicaba: ESALQ-USP. Available from: $<$ http://www.lerf.esalq.usp.br/parrel2005.php $>$. Access in: 20 de Maio de 2006.

RUNKLE, JR., 1981. Gap regeneration in some old-growth forests of the eastern United States. Ecology, vol. 62, no. 4, p. 1041-1051.

RUNKLE, JR., 1992. Guidelines and sample protocol for sampling forest gaps. Portland: Department of Agriculture, Forest Service, Pacific Northwest Research. 44p. General Technical Report (PNW-GTR-283).

SMALL, CJ. and McCARTHY, BC., 2002. Spatial and temporal variability of herbaceous vegetation in an eastern deciduous forest. Plant Ecology, vol. 164, no. 1, p. 37-48.

SUNDARAPANDIAN, SM. and SWAMY, PS., 1996. Influence of herbaceous species composition on fine root biomass production in disturbed and undisturbed deciduous forests of Western Ghats in India. Acta Oecologica, vol. 17, no. 2, p. 163-176.

TURNER, IM., TAN, HTW. and CHUA, KS., 1996. Relationships between herb layer and canopy composition in a tropical rain forest successional mosaic in Singapore. Journal of Tropical Ecology, vol. 12 , no. 6 , p. $843-851$.

VELOSO, HP. (Org.)., 1992. Manual técnico da vegetação brasileira. Rio de janeiro: IBGE. 92p. Manuais técnicos de geociências $\mathrm{n}^{\circ} 1$.

WANDERLEY, MGL. and VIEIRA, S., 2002. Nova espécie de Calathea G. Mey (Marantaceae) para o Brasil. Hoehnea, vol. 29, no. 2, p. 115-118.

ZICKEL, CS., 1995. Fitossociologia e dinâmica do estrato herbáceo de dois fragmentos florestais do estado de São Paulo. Campinas: Universidade Estadual de Campinas. 129p. Tese de Doutorado. 